\title{
9. Assessing Ministerial Responsibility in Australia
}

\author{
Richard Mulgan
}

\section{I}

Ministerial responsibility remains a key constitutional convention in Australia, as in all Westminster-derived systems. But its role continues to be contentious and disputed. Is it effective as an instrument of public accountability? Is it an outmoded principle that promises accountability but, in practice, allows both ministers and their officials to evade public scrutiny? Answers to these questions are elusive, in part because the actual requirements of the conventions of ministerial responsibility are a matter of dispute. Without agreement on what ministerial responsibility requires of ministers, one cannot expect to reach any straightforward conclusions about whether ministerial responsibility is doing its job. Moreover, ministerial responsibility is only one element in a complex system of government accountability and needs to be assessed within this larger context. Other accountability mechanisms have been subject to considerable evolution over the past 50 years, affecting the role played by ministerial responsibility. Concepts of 'traditional' ministerial responsibility drawn from an earlier era may no longer be applicable and may lead to distorted judgments about its present-day performance.

This chapter therefore begins by discussing the main issues surrounding the definition of ministerial responsibility, including a number of well-entrenched misunderstandings of the concept - for example, the supposed dependence on a distinction between 'policy' and 'administration' and its supposed requirement that ministers resign for mistakes made solely by their departmental officials. I then illustrate the effectiveness of present-day ministerial responsibility through analysis of a recent major public policy, the ill-fated Home Insulation Program (HIP) discussed by Chris Lewis in the previous chapter. Conventions of ministerial responsibility will be seen to have played a major role in securing public accountability of this program - though in the process they have distorted some of the attributions of personal responsibility and blame. 
According to standard constitutional doctrine, as represented in textbooks of constitutional law and political science (for example, Ratnapala 2007, 40; Summers 2006, 76-7), ministerial responsibility is a defining element in the conventions of responsible government. It includes collective ministerial responsibility, which obliges ministers to give public support to cabinet colleagues, especially the prime minister. It also covers individual ministerial responsibility, the subject of this chapter, which requires ministers to take responsibility for their portfolios, answering to parliament for the conduct of their departments and resigning in the case of failure or impropriety. In practice, this means that ministers are obliged to inform parliament and the public about any action taken by themselves or their officials and to impose remedies when failures have come to light. Resignation becomes an issue when the minister can be said to be personally responsible, particularly for matters of individual impropriety, illegality, negligence or incompetence. Whether ministers do resign depends on a range of factors, including the seriousness of the alleged failure, the extent of the minister's personal responsibility and a political calculation (ultimately by the prime minister) about the consequences for the government's standing of either accepting or rejecting the resignation (Mulgan 2002; Page 1990; Thompson and Tillotsen 1999; Weller 1999).

Both elements of this account - answering for departments and resignation in the case of failure - have been the subject of debate and criticism. Ministers' obligation to be responsible or accountable for the actions of their departments was traditionally taken to imply that public servants should remain anonymous, leaving the minister to be the sole public spokesperson for the department. The result was to shield public servants from direct scrutiny of their actions and prevent them from giving information about the inner workings of government departments. While ministers might be the right people to articulate and defend the general directions of departmental policy, public servants were often directly responsible for giving policy advice to ministers and for making routine administrative decisions for which they could not be held publicly accountable. Criticism of the monopolistic nature of ministerial responsibility as a mechanism of executive accountability led to the introduction of a number of supplementary mechanisms, including the ombudsman, freedom-of-information legislation, an expanded scrutinising role for parliamentary committees, the extension of government audit from financial compliance to the efficient and effective performance of government agencies, and increased judicial review of administrative actions. All such mechanisms had the effect of making public servants more directly accountable to the public. 
These accountability innovations were adopted throughout the 'Westminster' world, though the United Kingdom was a slower and more reluctant reformer because of more deeply entrenched commitment to traditional notions of ministerial responsibility and more pervasive fears that the rights of ministers might be diminished (Woodhouse 1994). Such objections, however, were overstated. The new mechanisms sought to preserve the sole responsibility of ministers for government 'policy' and to confine their own scope to matters of 'administration' where ministers and government policy were not directly involved. The distinction between 'policy' and 'administration' was never clear-cut and has always been interpreted according to the political dynamics of the particular context. But it has proved useful in discouraging the new accountability mechanisms from venturing too far into politically controversial areas.

The distinction between policy and administration, it should be noted, was not essential to the traditional conventions of ministerial responsibility. An influential recent analysis (Hughes 2003, 32-3, 244-6) implausibly links the Westminster model and ministerial responsibility to a model of traditional bureaucracy grounded in Weberian theories of bureaucracy and Woodrow Wilson's distinction between the realms of politics and administration. On this view, the Westminster model supposedly made ministers responsible for policy and bureaucrats responsible for administration - an unworkably rigid separation of functions that is then claimed to invalidate the conventions of ministerial responsibility because they rest on a fallacious assumption.

No such sharp division of roles, however, is required under traditional Westminster concepts where ministers were publicly accountable for all aspects of their departments, both general policy directions and more routine matters of administration. The distinction has only come to the fore with the new, supplementary accountability mechanisms, which seek to expose departmental officials to direct scrutiny while still protecting ministers' rights to control their departments. Officials are exempted from commenting on 'policy' and required to answer questions on 'administration' only. The distinction is often contested, particularly in parliamentary committees. Opposition politicians, anxious to embarrass the government politically, seek to extract damaging information about ministers from their officials. Public servants, on the other hand, being professionally loyal to the government of the day, use the concept of 'policy' as an excuse not to comment on politically contentious issues.

Even now, however, while public servants are excused from commenting on 'policy', the right of ministers to answer questions on matters of 'administration' remains intact. The new mechanisms supplement, rather than necessarily restrict, the accountability of ministers. Admittedly, under certain managerial practices associated with the new public management, such as the use of executive 
agencies and outsourcing, the responsibility and accountability of ministers have sometimes been restricted to setting policy, leaving the implementation (administration) to other, separately accountable officials or organisations. But the imposition of such a sharp differentiation of roles has been a deliberate attempt to restrict the traditional scope of ministerial responsibility (Mulgan 2003, Ch. 5). Indeed, public expectations of ministerial responsibility - that ministers should answer for all actions of their departments and not pass the buck to subordinates - have regularly undermined the managerialists' aim to keep politicians out of policy implementation (Polidano 1999; Woodhouse 1994, Ch. 12).

Any current assessment of ministerial responsibility therefore needs to recognise that it retains the ministers' right to answer for departments but no longer offers public servants the levels of anonymity and protection from scrutiny that it did in the past. It does not purport to be the sole channel of executive accountability and should not be criticised on these grounds. Instead, it needs to be seen simply as one element within an extensive range of accountability mechanisms to which executive government is now subject. Its effectiveness is therefore to be judged within this wider context in terms of its contribution to a general structure of accountability.

Controversy also attaches to the requirement that ministers should accept responsibility and resign in the case of failure. Individual ministerial responsibility has often been interpreted as if ministers are expected to exercise a form of 'vicarious' responsibility for their departments in the sense that they supposedly take on personal responsibility for all the actions of their departmental officials as if they were their own. On this view ministers must not only inform the public and see that administrative errors are rectified (informatory, explanatory and amendatory responsibility in Woodhouse's [1994] useful terminology) but they must also take the blame for and resign over all major failures committed by their officials (sacrificial responsibility). The notion that ministers should resign over the failures of their subordinates is widely held among members of the public and the commentariat, and provides ready ammunition for a claim that ministerial responsibility is ineffective. Because ministers never (or no longer) resign when they are not personally at fault, ministerial responsibility is said to be dead.

Vicarious responsibility, however, is a red herring, involving a misinterpretation of some key UK precedents (Dowding and Kang 1998; Marshall 1989; Woodhouse 1994, Ch. 2). All cases where ministers have been called on to resign over departmental failure involve a claim that the ministers in question personally share at least some of the responsibility for the failure, whether through their own negligence or incompetence or through their responsibility for the general policy and budgetary settings within which the failure occurred. Resignation 
without any personal blame at all is not, and never has been, a binding obligation on ministers. Repeated complaints that ministers 'no longer' exercise ministerial responsibility because they do not resign for faults wholly committed by their subordinates are ill informed.

Leaving vicarious responsibility to one side, ministers still frequently face calls for resignation for departmental failure when they can be said to share at least some of the blame. Actual resignation on these grounds is rare (Woodhouse 1994, 33-9). Indeed, in the Australian Commonwealth, no clear cases have occurred (Dowding, Lewis and Packer this volume; Page 1990; Thompson and Tillotsen 1999). Thus claims, such as those made by former prime ministers Gough Whitlam and Malcolm Fraser (quoted in Chapter 6 of this volume) that 'ministers no longer resign' for 'the failings of their policies or administration' (emphasis added), are without foundation. Ministers in Australia have never resigned for such failings.

The complete lack of observance of this principle, however, does not necessarily invalidate it: ministers ought to resign for presiding over departmental failure to which they have contributed personally. If the principle were invalid, ministers themselves, when called on to resign for such reasons, would surely argue that they had no such obligation and that their opponents were relying on an outmoded myth. In fact, they do not. Instead, they tend to resort to the red herring of vicarious responsibility and claim that ministers are not required to resign over matters that are entirely the fault of public servants. Thus, John Howard, as Prime Minister, facing a large number of calls for his ministers to resign (see Chapter 6), stated that 'it's never been the ministerial principle that you resign if something goes wrong in your department' (The Australian, 14 February 2001, quoted Mulgan 2002). But his wording was typically canny and designed to mislead, implying situations where ministers are not personally involved ('something goes wrong in your department').

As already noted, resignation never arises in such contexts. But this does not mean it could not do so if something went wrong in the department to which the minister had contributed in some way. In such cases, ministers do not deny the principle. Instead, they attempt to exonerate themselves by justifying their actions and rebutting charges of failure, toughing it out rather than accepting fault. Thus all sides appear to accept that ministers can be blamed for their part in departmental failures and would be obliged to resign if the failures were sufficiently serious and their role in them incontrovertible.

The responsibility of ministers for their departments is essentially similar to the corporate responsibility of chief executives in other sectors - for instance, heads of commercial companies, school principals, bishops or chairmen of cricket associations. All such people are expected to exercise general oversight of all 
aspects of their organisations, to answer to the public for their organisation's performance and to accept personal responsibility for matters directly within their control. When their organisations fail, they can expect to face calls for their resignation. As with ministers, however, such calls are seldom accepted. Most chief executives either seek to rebut the charges of failure or, while accepting that their organisation may have performed badly, argue that they should remain in office to repair the damage. Because responsibility for most collective failures lies with various individual members as well as with corporate culture and processes, pinning blame on a single person is notoriously difficult (the problem of 'many hands': Bovens 1998). Corporate leaders, though personally tarnished by failure, can usually escape any obligation to shoulder sole or major blame (Mulgan 2002).

That ministers similarly do not respond positively to calls for their resignation in cases of collective failure is therefore hardly surprising. More anomalous, perhaps, is that the obligation to resign figures so prominently in standard definitions of ministerial responsibility. In the case of a company executive or a bishop, we do not usually say that their role is twofold: first, to manage their company or diocese well and, second, to resign in the case of personal fault or collective failure. An obligation to resign may be implicit in a general obligation to manage competently and honestly, but it is not singled out for special mention in the job description.

Indeed, the obligations of ministers can be similarly stated without explicitly mentioning resignation, as in the Government's own statement of Standards of Ministerial Ethics (Department of the Prime Minister and Cabinet 2010), which summarises the responsibility and accountability of ministers without reference to any obligation to resign. Nonetheless, the emphasis on resignation, including resignation for departmental failure, in standard accounts of ministerial responsibility, while arguably anomalous, cannot be ignored. It continues to be kept alive in public discourse and political culture, not only by opportunistic opposition politicians but also by members of the general public. It must therefore be considered a central element in the conventions, even if it is never acted on.

\section{III}

The Home Insulation Program (originally the Homeowner Insulation Program; HIP) was announced in February 2009 as part of the Federal Government's package of economic measures designed to counter the effects of the global financial crisis of 2008 (for a detailed account of the program, see Auditor-General 2010). Like other policies in the package, the HIP was intended to generate 
short-term employment and stimulate consumption while leaving behind a long-term benefit - in this case, improved insulation and energy efficiency in domestic housing. The program provided financial incentives for the installation of home insulation, through payments of up to $\$ 1600$ for homeowners or $\$ 1000$ for landlords or tenants.

The initial phase of the program ran from February to June 2009 and required homeowners to seek reimbursement for work completed (more than 73000 rebates were paid out in the five-month period - an average of about 15000 per month). During the second phase, beginning on 1 July 2009, payment procedures were streamlined, allowing installers to claim directly through the Medicare network. In the nine months till the program was suspended at the end of March 2010, a further 1.16 million payments were made (an average of nearly 180000 per month, or about 12 times the rate of payments in the first phase). During the same period the number of insulation installation businesses increased from about 200 before the program to more than 10800 at its peak (Auditor-General 2010, 99, note 106).

Primary responsibility for administering the program lay with the Department of the Environment, Water, Heritage and the Arts (DEWHA), under its minister, Peter Garrett. To manage the program, the department established a Project Control Group, including representatives from other departments, such as Medicare, which handled the registration of installers and payment of rebates. It also called on a range of consultants, including Minter Ellison for risk assessment, KPMG for the business model design, Protiviti and PriceWaterhouseCoopers for compliance and audit, and Ernst and Young for a fraud control plan. The Project Control Group reported to the Office of the Coordinator-General, in the Department of the Prime Minister and Cabinet, which oversaw all the stimulus initiatives, with a particular view to making sure that spending targets were being met. While State governments were not directly involved in the administration of the program, State fair trading organisations and consumer affairs departments were relied on for dealing with individual complaints from the public.

Initial complaints about the program came from relevant stakeholders, including established members of the insulation trade and electrical contractors concerned about the threats to standards and safety raised by an influx of inexperienced installers. During the second phase, from mid-2009, problems also arose over shortages of ceiling batts; certain major suppliers were accused of monopolising stock and crowding out smaller competitors. Unscrupulous operators were reported to be claiming for work that was inadequately carried out. In midOctober 2009, the death of an installer, followed by two more deaths in November, raised major safety concerns. In response, the department introduced a number changes to the scheme, including targeted safety inspections of foil installations 
in Queensland, the mandatory use of downlight covers and the banning of metal staples. In December, further training materials from installers were released and installers were required to provide evidence of minimum training (AuditorGeneral 2010, Appendix 2).

In early February 2010, a fourth fatality followed by increasingly strident public criticism of the scheme prompted further changes, including the suspension of foil insulation (on 9 February) and electrical inspections of all installed foil insulations (on 10 February). Finally, on 19 February the entire program was scrapped. Shortly thereafter, responsibility for winding up the program and dealing with the outstanding issues of inspection and compensation was transferred to another department, the Department of Climate Change and Energy Efficiency (DCCEE), under the direction of the Minister for Climate Change, Greg Combet.

Public accountability for the program developed through a number of processes. To begin with, most discussion took place through the normal channels of consultations with stakeholders. Departmental officials held regular meetings with relevant industry representatives and received feedback from interested parties and disgruntled consumers; however, after the reporting of deaths associated with the program in October and November 2009, the program began to attract public criticism in Parliament. In mid-November, a number of backbench Opposition MPs used their allotted time in adjournment debates to raise issues from their constituencies about the faulty implementation of the scheme - for instance, rorting and intimidation by installers and stockpiling of batts by major suppliers (Coulton 2009; Marino 2009; Schultz 2009).

The first major parliamentary attack on the program came the week after the third death on 25 November (House of Representatives Hansard 12873). Greg Hunt, the shadow minister for climate change, environment and water, raised the Government's whole environmental and water programs as 'a matter of public importance' (House of Representatives Hansard 12873), devoting most of his speech to the insulation program. He criticised the minister, Garrett, for being responsible for a flawed program that was open to fraud and substandard work as well as to major safety risks. Hunt relied heavily on information from the electrical contractors' professional association, the National Electrical and Communications Association (NECA), which said that it had written to the minister as early as March 2009, pointing out the dangers of fire and electrocution from careless installation of insulation. Hunt also called for an immediate inquiry by the Auditor-General.

In response (House of Representatives Hansard 12877), the minister pointed to the overall success of the program, in terms of houses insulated and people employed, and to the constant adjustments being made to reduce opportunities 
for fraud and to increase safety. He expressed regret over the deaths and other instances of failure but asserted that the Government had given priority to safety concerns, pointing out that safety inspection was a matter for State authorities. There was no need for an immediate audit report, the Auditor-General having agreed to audit the program later 'in the ordinary course of business'.

The tempo of criticism quickened when Parliament resumed after the Christmas break. The Leader of the Opposition, Malcolm Turnbull, who was reported to have been in favour of such a scheme when Minister for the Environment in the previous Howard Government, had been replaced with the more aggressive Tony Abbott. Moreover, a fourth program-related fatality, in early February, reignited safety concerns and deepened the impression of a minister and government with blood on their hands. The Opposition went after Garrett, with all available parliamentary weapons. In Question Time in the House of Representatives, for three consecutive sitting days (February 11, 22 and 23), every Opposition question concerned the minister's conduct of the insulation program. Most were directed to the minister himself; a few were aimed at the Prime Minister, querying his continued support for Garrett.

On the next two days (24 and 25 February), when the Prime Minister had begun to take charge of the issue and Garrett was being sidelined, the focus of questioning moved more to the Prime Minister and away from the minister. But the insulation program itself remained the subject of all Opposition questioning. The Opposition also pursued its attack through motions of censure $(11,22$ and 24 February). Media interest was intense, as journalists reflected public anger at the program's failings, especially the four fatalities, and as the press gallery, in particular, scented the possibility that a minister might be fatally damaged. By the time Parliament met again on 9 March, Garrett no longer had any formal responsibility for the program, which had been moved to a different department under another minister. The Opposition's focus at Question Time then moved on to other topics.

While the House of Representatives, which included the minister, the Prime Minister and the Leader of the Opposition, was naturally the key forum of Opposition attack, questions were also raised in the Senate, directed particularly at Senator Mark Arbib. Arbib was not only Senate spokesman for the Environment Minister but was also indirectly involved in the insulation program as minister in charge of the Office of Coordinator-General in the Department of the Prime Minister and Cabinet, which was overseeing progress of all the various programs making up the economic stimulus package. The Opposition was also able to use the Senate Committee on Environment, Communications and the Arts to question senior department officials, particularly about the minister's personal role in overseeing the program. 
In their questioning of the minister, the Opposition concentrated on issues where his own personal fault and responsibility might be more readily established. For instance, they quizzed him repeatedly on warnings about safety he had received from NECA and others, and on why he had apparently taken so long to act on them. They also hammered the question of when he had first received a risk assessment prepared for the department by the consulting firm Minter Ellison. They evidently hoped to catch him in a contradiction that would constitute the offence of misleading Parliament. To all such questions the minister replied that the Government had always given priority to safety issues, that his department had regularly and conscientiously reacted to a variety of warnings and risk assessments, and that he himself had acted responsibly on the advice of his department.

The Leader of the Opposition also explicitly referred to familiar debating points about Westminster conventions of ministerial responsibility. Ministers were responsible for the administration of their departments and should not hide behind their officials (for example, 11 February 2010, House of Representatives Hansard 1211; 22 February 2010, House of Representatives Hansard 1324). The minister's claim to have responsibly followed advice was inadequate, especially when he had been repeatedly warned about safety issues. In addition, obfuscation over the Minter Ellison report amounted to misleading Parliament. Either he should resign or the Prime Minister should sack him.

Senior government ministers came to Garrett's defence by arguing that he could not be responsible for all the details of the program's implementation. According to Julia Gillard, the Deputy Prime Minister, Garrett could not be expected to be up in every roof inspecting each installation (quoted in The Australian, 18 February 2010). Lindsay Tanner, the Minister of Finance, was reported to have said that government could not be expected 'to dot the i's or cross the t's' (11 February 2010, House of Representatives Hansard 1207). For debating purposes, they thus introduced the red herring of vicarious responsibility, inferring that Garrett was supposedly being held responsible for all actions of officials even when he could have had no personal responsibility for them. Such a charge could then be dismissed as unreasonable.

The Opposition's argument, however, did not rely on questionable notions of vicarious responsibility. They argued on the much stronger ground that the minister was personally negligent and blameworthy for not doing more to ensure tighter safety standards after he had personally received a series of warnings about safety issues. As the extent and seriousness of the program's failures gradually emerged in the media blitz generated by the Opposition's attack, the minister's defence - that he had done all that could be reasonably expected of a responsible minister - rang increasingly hollow. No evidence was found of his actually having misled Parliament over the receipt of documents, but his 
apparently passive reliance on official advice suggested a lack of responsible leadership. The Prime Minister refused to countenance the minister's formal resignation, presumably because it would have handed an obvious victory to the Opposition. But he was forced to accept the substance of the Opposition's case as a means of defusing the continuing negative publicity. Not only was the program suspended, but also the minister was stripped of formal responsibility for clearing up the mess over which he had presided. He remained in cabinet but with his political reputation seriously, perhaps permanently, damaged.

In the case of the ill-fated HIP, the conventions of ministerial responsibility clearly proved a powerful instrument of public accountability. They channelled the Opposition's desire to damage the Government into a concerted, sharply focused attack on a weak minister defending a badly botched program. The repeated calls for the minister's resignation, sanctioned by well-entrenched Westminster conventions, forced the minister into a desperate and ultimately unconvincing justification of his own personal role. The minister may not have formally resigned but the argument that he ought to resign carried great public resonance, particularly in the light of the fatalities. The gripping political drama played out daily in Question Time generated widespread public interest and helped to publicise the program's many problems. In a matter of weeks, the program was seriously curtailed then scrapped altogether, with the Government committed to generous recompense for those who had lost financially or whose homes were at risk of fire or causing electrocution.

Ministerial responsibility provided the spearhead of public accountability of the Home Insulation Program. But the political pressure that it built up also set in train other accountability mechanisms that were able to move at a more deliberate pace. The Senate Standing Committee on Environment, Communications and the Arts had already, in late 2009, begun an inquiry into the Energy Efficient Homes Package. The inquiry received added impetus after the political crisis in February 2010. The committee held a number of public meetings in February and March and eventually reported in July 2010; however, reflecting the partisan passions aroused by the program, the committee divided along party lines, with the Opposition Coalition senators returning a majority report, government senators submitting a minority report and the Greens entering dissenting comments.

In addition, the Department of the Prime Minister and Cabinet commissioned a review of administrative aspects of the program from Dr Allan Hawke, an experienced former secretary of a number of Commonwealth departments. Dr Hawke reported in April (Hawke 2010). While not seeking to exonerate the departmental officials running the program, he did point to a number of extenuating factors beyond their control. He also sought to estimate the benefits, as well as the costs, of the program. 
Finally, one of the first actions of the new minister, Greg Combet, was to request the Auditor-General to conduct an audit of the program (a request already made several times by the Opposition spokesman, Greg Hunt). The Auditor reported in October (Auditor-General 2010), providing a comprehensive and balanced assessment of the program, particularly the part played by Commonwealth public servants. Further accountability measures, through State judicial systems, were also undertaken in relation to individual installers.

Later reports naturally added a wealth of further information, additional to the relatively few facts available at the time the minister was being questioned in Parliament. For instance, it is now clear that the documents from the NECA and Minter Ellison, of which the Opposition made great play, were only a fraction of the relevant advice and feedback received and processed by members of the department as they administered the program and reported regularly to the minister.

The most telling general conclusion to emerge from the later reviews is that the prime cause of the program's failure was the urgency imposed on the department (DEWHA) by the need to roll out the program as quickly as possible. Moreover, this imperative was imposed from the outside, through the Department of the Prime Minister and Cabinet (PM\&C) in its pursuit of the Government's overall strategy of economic stimulus spending. DEWHA, which lacked experience in direct program delivery, was not given the resources, staff or time to implement the program effectively. Within the Commonwealth Public Service, therefore, administrative responsibility for the failure lies more with PM\&C, which helped drive the spending agenda and whose secretary, as head of the Public Service, was known to be very critical of bureaucratic caution and risk aversion in line departments. Political responsibility, in turn, rests with the Prime Minister and his economic ministers, rather than with the Minister for the Environment whose concerns were overruled by senior colleagues.

That excessive speed was a major driver of failure was clear to the Opposition and occasionally mentioned by them in their attacks on the minister. But so long as their focus was firmly fixed on claiming the minister's scalp, the speed factor could not become part of the central thrust of their campaign because it was not something for which the minister could be held personally responsible. Indeed, the more that is revealed about the inner political and bureaucratic dynamics surrounding the program, the less blameworthy Garrett appears. Not only was he doing the bidding of the Prime Minister and his cabinet colleagues in pressing on without delay, but he was also not very well served by his departmental officials who, in the view of the Auditor-General, could have done more to keep him fully informed about the problems facing the program (Auditor-General 2010, 34-5). Garrett could perhaps be accused of excessive loyalty to his party or of moral timidity in not speaking out more forcefully about the program's 
obvious faults once they emerged. But he was hardly the leading instigator or primary cause of these faults as depicted by the Opposition in their desire to force his resignation.

It was only after responsibility for the program was removed from Garrett that the Opposition began to turn their attention to the Prime Minister himself, who carried primary responsibility for the overall stimulus spending and for the overriding economic imperative to spend funds quickly. By drawing the full initial force of the Opposition's broadside and not passing the buck, Garrett had helped to protect his leader and senior colleagues from their due share of blame for the program while the media frenzy was at its height. Indeed, according to journalist Barrie Cassidy, there were some members of the government caucus who felt that the Prime Minister had unfairly let Garrett take responsibility for the program's failure (ABC 2010). Party gratitude was presumably one factor in Rudd's willingness to keep Garrett in cabinet even though his responsibilities were significantly reduced.

Concentration on the directly accountable minister not only helped to shield other ministers who carried more of the personal responsibility, but it also deflected immediate attention from other organisations and individuals who shared some of the blame - for instance, the departmental officials directly responsible for the day-to-day administration of the program. Even when Opposition MPs had access to senior members of DEWHA in the senate committee, their focus remained fixed on the role of the minister and his office and on trying to find evidence of their negligence. It was only the subsequent Hawke and AuditorGeneral's reports that clearly documented the department's actions and pointed to serious deficiencies that were the responsibility of the secretary and senior officials rather than the minister. Ministerial responsibility on its own would have left such matters unexamined.

Beyond the Commonwealth Public Service, other contributors escaped even belated scrutiny. For example, the bevy of consulting firms used by DEWHA (including the infamous Minter Ellison) was beyond the terms of reference of both Hawke and the Auditor-General. So too were the relevant State government agencies responsible for occupational health and safety. The ripples of accountability prompted by the Opposition's attack on the minister petered out before a complete account could be made of all the contributing factors.

\section{IV}

What general conclusions about the effectiveness of ministerial responsibility as an accountability mechanism can be drawn from this case? To begin with, the exceptional nature of the Garrett affair must be conceded. It involved an 
unusual intensity of hostile questioning and adverse publicity clearly derived from the scandalous failures of the program, particularly the four fatalities, for which the minister and the Government could be blamed. Nonetheless, it illustrates continuing aspects of ministerial responsibility that may be dormant for much of the time but the prospect of which animates much government and opposition behaviour.

First, oppositions rely heavily on the conventions of ministerial responsibility as a key set of weapons in trying to hold the government accountable and thus improve their own electoral prospects. In this they are followed by the press gallery and the national media, which concentrate on Question Time in their reporting of politics and which find displays of weakness or incompetence by individual ministers particularly newsworthy. The accountability effects of this parliamentary contest are profound. Ministers must answer not only in parliament but also directly to the media. Though they can and do frequently prevaricate and try to avoid answering the questions asked, they must face the public consequences of such evasion.

Second, the thrust of opposition questioning, determined by the electoral incentive of embarrassing their political opponents, is towards the personal responsibility of individual ministers. Questions may seek information about the performance of government departments but typically as a means of securing evidence to undermine the credibility of ministers. Third, the principle that ministers ought to resign (or be dismissed) for incompetence in running their departments is widely acknowledged and provides an underlying assumption for opposition attacks on vulnerable ministers (and for ministerial defences of their actions). Though ministers may not actually resign on these grounds, their failure to do so on matters of serious policy failure tarnishes their reputation and inflicts political damage not only on themselves but also on their government as a whole.

At the same time, the concentrated focus on individual ministers can weaken public accountability if it shifts the spotlight of public attention too far away from others who share responsibility for a particular policy or program. By leaving the individual portfolio minister to bear the brunt of public attack, other ministers - especially the prime minister, who carries ultimate responsibility for the government as a whole and therefore for all major policies - can escape immediate scrutiny. Ultimately, no doubt, the voters have the chance to hold the prime minister and the government to account through the ballot box, but such an assessment lacks the sharp focus of direct parliamentary questioning.

In addition, the role of public servants who play a major part in developing and implementing policy tends to be overlooked in the opposition's (and the media's) preoccupation with the fate and reputation of ministers. Such political 
considerations heavily influence the agenda not only of parliamentary questions but also of parliamentary committees. These committees, in theory, are intended to provide opportunities for directly examining the conduct of public servants and their administration of government agencies. In practice, politically partisan factors predominate (Mulgan 2008). It is for this reason that less politicised accountability agencies, such as the audit office and the ombudsman, are so important. Their avoidance of controversial matters of 'policy' allows them to focus their attention primarily on the actions of public officials.

As is now generally recognised, ministerial responsibility, on its own, cannot provide comprehensive accountability of all the activities of government. Other, supplementary, accountability institutions are also vital. But ministerial responsibility, properly understood in context, is still a very powerful and effective accountability mechanism. From the point of view of the general public and the media, ministers are the most obvious point of contact over matters of community concern. Within the government apparatus, too, the relevant minister remains the natural spokesperson for each agency and loyal support for the minister in this public role is a key value for professional public servants.

These expectations reinforce the centrality of ministerial responsibility in our system of government. Indeed, some commentators complain that ministers and their immediate circle of advisers are too powerful in Westminster-style systems such as Australia's (Hughes 2003). On this view, hierarchical accountability through the minister fosters excessive, top-down bureaucratic control and stifles the development of flexible, bottom-up, citizen-centric government that is possible in more devolved political systems, such as those of the United States or some European countries. But whatever the merits of ministerial responsibility as a principle in institutional design, its continuing impact is undeniable.

\section{References}

Auditor-General. 2010. Home Insulation Program. Audit Report no. 12 2010-11. Canberra: Australian National Audit Office. <http://www.anao.gov.au>

Australian Broadcasting Corporation (ABC). 2010. The Drum, 18 October, $<$ http://www.abc.net.au/thedrum $>$

Bovens, M. 1998. The Quest for Responsibility - Accountability and Citizenship in Complex Organisations. Cambridge: Cambridge University Press.

Coulton, M. M. 2009. House of Representatives Hansard 12222, 19 November. Canberra: Parliament of Australia. 
Department of the Prime Minister and Cabinet. 2010. Standards of Ministerial Ethics. Canberra: Department of the Prime Minister and Cabinet. <http:// www.dpmc.gov.au/guidelines/index.cfm>

Dowding, K. and W.-T. Kang. 1998. 'Ministerial Resignations 1945-97'. Public Administration 76(3): 411-29.

Hawke, A. 2010. Review of the Administration of the Home Insulation Program. Canberra: Department of the Prime Minister and Cabinet.

Hughes, O. 2003. Public Management and Administration. Third edition. Basingstoke, UK: Palgrave.

Marino, N. B. 2009. House of Representatives Hansard 12234, 19 November. Canberra: Parliament of Australia.

Marshall, G. 1989. 'Individual Responsibility: Some Post-War Cases'. In Ministerial Responsibility, ed. G. Marshall, pp. 127-33. Oxford: Oxford University Press.

Mulgan, R. 2002. 'On Ministerial Resignations (and the Lack Thereof)'. Australian Journal of Public Administration 61(2): 121-7.

Mulgan, R. 2003. Holding Power to Account. Basingstoke, UK: Palgrave Macmillan.

Mulgan, R. 2008. 'The Accountability Priorities of Australian Parliamentarians'. Australian Journal of Public Administration 67(4): 457-69.

Page, B. 1990. 'Ministerial Resignation and Individual Ministerial Responsibility in Australia, 1976-89'. Journal of Commonwealth and Comparative Politics 28: $141-61$.

Polidano, C. 1999. 'The Bureaucrat Who Fell Under a Bus'. Governance 12: 20129.

Ratnapala, S. 2007. Australian Constitutional Law: Foundations and Theory. Melbourne: Oxford University Press.

Schultz, A. J. 2009. House of Representatives Hansard 11776, 16 November. Canberra: Parliament of Australia.

Summers, J. 2006. 'Parliament and Responsible Government'. In Government, Politics, Power and Policy in Australia, eds A. Parkin, J. Summers and D. Woodward, pp. 68-92. Sydney: Pearson Education. 
Thompson, E. and G. Tillotsen. 1999. 'Caught in the Act: The Smoking Gun View of Ministerial Responsibility'. Australian Journal of Public Administration 58(1): 48-57.

Weller, P. 1999. 'Disentangling Concepts of Ministerial Responsibility'. Australian Journal of Public Administration 58(1): 62-4.

Woodhouse, D. 1994. Ministers and Parliament: Accountability in Theory and Practice. Oxford: Clarendon Press. 